Woodward, F. I. \& Sheehy, 1979. Microclimate, photosynthesis and growth of lucerne (Medicago sativa L.). II. Canopy structure and growth. Annals of Botany 44: 709-719.

This synopsis is based on a doctoral thesis, Agricultural University, Wageningen, 1985. $x+182$ pp., 89 figs., 26 tables, 269 refs. English, with Spanish and Dutch summaries.

Available as paper copy (order R028P, $f 30$ including postage) or on microfiche (order R028M, f 17.50) at: NARD, clo Pudoc, P.O. Box 4, 6700 AA Wageningen, Netherlands (telex 45015 blhwg nl).

\title{
Digestibility of plant fractions from different genotypes and the predictability of quality of forage maize in northwest Europe
}

P. C. Struik (Department of Field Crops and Grassland Science, Agricultural University, Haarweg 333, 6709 RZ Wageningen, Netherlands)

Received 20 December 1984; accepted 1 February 1985

\begin{abstract}
Differences in digestibility of plant parts from five genotypes of forage maize are described and related to the differences in whole-plant digestibility of crops, grown under different conditions. Plant parts differ greatly in digestibility, and their proportions of the dry matter of the total plant are variable, due to numerous physical, chemical, biological and genetic factors. Yet, whole-plant digestibility is fairly constant and predictable.
\end{abstract}

Key-words: forage maize, digestibility, genotype, brown-midrib, cell wall.

Introduction. Forage maize (Zea mays L.) is grown as feed for livestock reared for meat and milk production. The value of a maize crop is determined by factors affecting yield, preservation and feeding value. This paper is focused on feeding value estimated by digestibility in vitro and by cell-wall content.

Material and methods. Five genotypes of forage maize were sown on 26 April 1979 on a sandy soil at a density of 7 plants $\mathrm{m}^{-2}$. Twenty random plants were harvested on 11 October 1979 and separated into different fractions. Material was chopped, dried at $70^{\circ} \mathrm{C}$, weighed and ground. Chemical and biological analyses were carried out as described by Struik (1983a, b).

Growing conditions and procedures of sampling, handling and chemical analyses 
of the other experiments mentioned in this paper have been described by Struik (1983a, b, c) and Struik \& Deinum (1982).

Results. Table 1 shows the organic-matter digestibility $\left(D_{o m}\right)$ of various plant parts of two commercial cultivars and three brown-midrib $\left(\mathrm{bm}_{3}\right)$ mutants (average only). Plant parts varied greatly in digestibility, whereas genotypic differences were also very large. Differences between fractions were caused by differences in cell-wall content (cwc \%) and cell-wall digestibility $\left(\mathrm{D}_{\mathrm{cwc}}\right)$. Genotypic differences were consistent over all fractions except for the kernels. These differences were mainly attributable to differences in $D_{c w c}$. Fractions with low levels of structural tissue (e.g. kernel, pith and leaf lamina without midrib) showed the smallest genotypic variation in $\mathrm{D}_{\mathrm{om}}$.

The individual fractions showed their maximum increase in dry weight during different stages of the plant's development. Thus the production of ultimately poorly digestible cell-wall components (e.g. in rind and tassel), of very digestible cell-wall components (e.g. in pith, leaf lamina and ear) and of wholly digestible cellular contents (e.g. the starch in the kernels) occurred at different, but partly overlapping stages. The amount and nature of these components can be affected separately by weather and other growing conditions.

In a uniform crop, all plants are approximately in the same stage of development. Preliminary data indicated that plant-to-plant variation in $\mathrm{D}_{\text {om }}$ is very low.

In all field experiments carried out in a five-year period the cell-wall material of the whole plant showed a continuous decline in digestibility over time from

Table 1. Apparent digestibility (in $\%$ of the organic matter; $D_{o m}$ ) of ten morphological fractions for different genotypes.

\begin{tabular}{|c|c|c|c|}
\hline & \multicolumn{3}{|l|}{ Hybrid } \\
\hline & Eta Ipho & Circé & $\mathrm{bm}_{3}{ }^{1}$ \\
\hline Tassel & 44.0 & 47.6 & 69.4 \\
\hline $\mathrm{Cob}$ & 59.7 & 68.4 & 78.1 \\
\hline Kernel & 88.1 & 88.6 & 87.7 \\
\hline Husk + shank & 63.1 & 65.5 & 79.2 \\
\hline Midrib & 46.4 & 56.3 & 71.2 \\
\hline Leaf lamina minus midrib & 71.6 & 76.7 & 76.3 \\
\hline Leaf sheath & 47.7 & 55.6 & 68.7 \\
\hline Rind of main stem & 44.9 & 54.4 & 65.9 \\
\hline Pith of main stem & 65.3 & 73.6 & 81.0 \\
\hline Tiller & - & - & 82.1 \\
\hline Whole plant (calculated) ${ }^{2}$ & 71.8 & 75.4 & 81.4 \\
\hline
\end{tabular}

${ }^{1}$ Average of INRA $240 \mathrm{bm}_{3}$, INRA $188 \mathrm{bm}_{3}$ and LG $11 \mathrm{bm}_{3}$. Seed of these genotypes was kindly provided by Dr A. Gallais (INRA, France).

2 These calculated in vitro digestibilities of the whole plant agree with the in vivo digestibilities estimated using adult wethers fed at about maintenance on silages made from the same crops and reported by Deinum et al. (1983).

Neth. J. agric. Sci. 33 (1985) 
emergence until final harvest. The rate of decline was fastest during vegetative growth and depended on genotype. During the period of leaf and stem formation, the relative rate of cell-wall production was faster than the relative rate of production of cell contents. The cwc \% therefore increased until flowering. Since cell-wall production stopped after successful grain set, the cwc \% declined during grain filling. All genotypes investigated showed the same pattern. Each genotype reached about the same maximum cwc $\%$. Since the amounts of cell-wall components and the flowering dates differed, the rates and durations of the decline in cwc \% varied. Because of the high $\mathrm{D}_{\mathrm{cwc}}$ commonly found in cool climates, the consequences of these genotypic differences were of minor importance for $\mathrm{D}_{\mathrm{om}}$.

Reduced photosynthesis (due to poor conditions and plant senescence) associated with a continuation of the decrease in $D_{\text {cwc }}$ caused a reduction of the $D_{\text {om }}$ at the end of the growing period. The maximum $D_{\text {om }}$ was reached earlier than the maximum dry-matter yield.

Discussion. Struik (1983a, b, c) and Struik \& Deinum (1982) described how the $\mathrm{D}_{\text {om }}$ of forage-maize crops responds to (short-term changes in) photoperiod, light intensity and temperature. Some steps in the plant's development prove to be especially sensitive to climatic conditions e.g. tassel initiation, silking and grain set. High temperatures, long days and low light intensity during certain short periods are therefore adverse for the $\mathrm{D}_{\text {om }}$ of the whole plant. Within normal ranges, however, these climatic factors only have a limited impact.

If ear development is not hampered by water stress, $D_{c w c}$ hardly varies between years. Cwc \% is more variable but this has only limited repercussion on $\mathrm{D}_{\text {om }}$ and cwc \% is easy to predict based on the plant's appearance. Thus the $\mathrm{D}_{\text {om }}$ of a certain hybrid is fairly constant and can be estimated if weather, plant development and 'normal' $D_{\text {om }}$ of the hybrid are known. For the correction of this normal value, water supply during grain set, light intensity during September, harvest date and abundance of vegetative growth (e.g. estimated by plant height) should be considered. Although refinement is certainly necessary, the first attempt to present yearly fixed $\mathrm{D}_{\mathrm{om}}$ values to farmers in the Netherlands is promising.

\section{References}

Deinum, B., A. Steg \& G. Hof, 1983. Measurement and prediction of digestibility of forage maize in the Netherlands. Animal Feed Science and Technology 10: 301-313.

Struik, P. C., 1983a. The effect of switches in photoperiod on crop morphology, production pattern and quality of forage maize (Zea mays L.) under field conditions. Mededelingen Landbouwhogeschool Wageningen $83-2,27$ pp.

Struik, P. C., 1983b. Effect of temperature on development, dry-matter production, dry-matter distribution and quality of forage maize (Zea mays L.). An analysis. Mededelingen Landbouwhogeschool Wageningen 83-3, 41 pp.

Struik, P. C., 1983c. The effects of short and long shading, applied during different stages of growth, on the development, productivity and quality of forage maize (Zea mays L.). Netherlands Journal of Agricultural Science 31: 101-124.

Struik, P. C. \& B. Deinum, 1982. Effects of light intensity after flowering on the productivity and quality of silage maize. Netherlands Journal of Agricultural Science 30: 297-316. 
This synopsis is based on a part of a doctoral thesis entitled 'Physiology of forage maize (Zea mays L.) in relation to its production and quality', Agricultural University, Wageningen, 1983. ix +252 pp., 62 figs, 53 tables, 598 refs. English; English and Dutch summaries. The major part of this thesis has been published elsewhere.

Available as paper copy (order R009P, $f 40$ including postage) or on microfiche (order R009M, f 22.50 including postage) at: NARD, c/o Pudoc, P.O. Box 4, 6700 AA Wageningen, Netherlands (telex 45015 blhwg $\mathrm{nl}$ ).

\title{
A stochastic model for the simulation of management decisions in dairy herds, with special reference to reproductive performance
}

A. A. Dijkhuizen (Department of Farm Economics, Agricultural University, Hollandseweg 1, $6706 \mathrm{KN}$ Wageningen, Netherlands), Sj. Hibma ${ }^{1}$ (Zootechnical Institute, Veterinary Faculty, P.O. Box 80156, 3508 TD Utrecht, Netherlands) and J. A. Renkema (same address as the senior author)

Received 29 November 1984; accepted 1 February 1985

\begin{abstract}
A computer simulation model to study management decisons in dairy herds was developed. The first objective of the present model is to quantify the (economic) effects of different policies with respect to (re)productive failure and culling. The structure of the model also allows study of other aspects of management such as decisions regarding sire selection and feeding of the herd.

Key-words: simulation model, dairy cattle, economics, fertility, culling policy.
\end{abstract}

Introduction. Every farmer must frequently decide which cows should stay in the herd until further notice. To support him in making this decision, economic criteria for individual cows which differ in age, productive capacity and reproductive performance have been developed by using a replacement model in which the probabilities of disposal were taken into account in a deterministic way (Dijkhuizen et al., 1985). In the latter model, the critical production level below which it is not profitable to (re-)inseminate cows at different stages in each lactation was determined. It appeared to be desirable to gain further insight into the potential advantage of making replacement decisions over a number of years within different herds, based

\footnotetext{
${ }^{1}$ Present address: Nautical College 'Willem Barentsz', Dellewal 8, 8881 EG West-Terschelling, Netherlands.
} 